Vol. 2 No. 1- April 2021

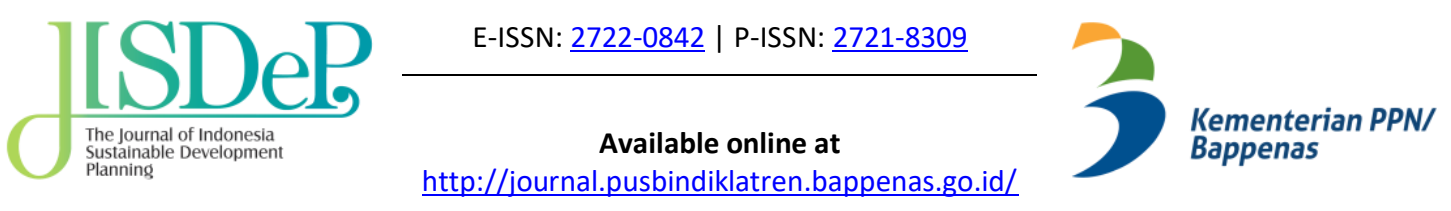

Research Paper

\title{
Trends and Situation of Forest Fire in Indonesia 2015-2018, Based on Three
}

\section{Factors:}

\section{Peatland, Timber Concession, and Forest Area}

\author{
Mila Soraya \\ Master of Economic Planning and Development Policy, Faculty of Economics and \\ Business University of Indonesia, Depok, Indonesia \\ milasoray@gmail.com
}

\begin{abstract}
This research addresses the reoccurrence of forest fires and their size with regional-spatial information. This study is attained to the Sustainable Development Goal in the year 2030 (climate action and life on land) and is consistent with the mission of JISDeP. Probit and tobit regression analyses were applied to the regional-spatial panel data from 2015 to 2018 in Indonesia with the observations of forestfire events, peatland, forest area, and timber concession on an annual basis. Such analyses would characterize the possible determinants for the forest fire reoccurrence together with their sizes. Comparatively, this study tries to fill the gap by examining the reoccurrence of forest fires. This research tries to fill in the gap on studies about land and forest fires by combining quantitative analysis using probit and tobit regression and using spatial approach of peatland, forest and timber concession area. The regression results reveal the following outcomes. The first outcome is whether forest fire reoccurrence positively (negatively) associated with peatland and forest areas (timber concession). Second, forest fires tend to decrease with the repetition of past forest fires but increase with timber concession, peatland, and forest areas. Overall, these results imply that the reoccurrence of forest fires and their sizes is highly concerned with timber concession and types of areas, suggesting that Indonesia should organize the policies regarding forest timber concession and areas to reduce forest fires and the associated damage.
\end{abstract}

Keywords: forest fire reoccurrence, peatland, timber concession, forest area

ARTICLE INFO
Received: November 01,2020
Received in revised form: March 16, 2021
Accepted: April 01, 2021

doi: 10.46456/jisdep.v2i1.89 (C) 2021 The Author
JISDeP - The Journal of Indonesia Sustainable Development Planning Published by Centre for Planners' Development, Education, and Training (Pusbindiklatren), Ministry of National Development Planning/ National Development Planning Agency (Bappenas), Republic of Indonesia
Address: Jalan Proklamasi 70,

Central Jakarta, Indonesia 10320

Phone: +62 $2131928280 / 31928285$

Fax: +622131928281

E-mail:

journal.pusbindiklatren@bappenas.go.id

Supported by Indonesian Development Planners Association (PPPI) 


\section{Introduction}

The World Bank estimates that, in 2015, forest fires cost Indonesia at least USD 16.1 billion (IDR 221 trillion) with a size of 2.6 million hectares. It is about four and a half times the size of Bali. The government has paid much attention to business permit holders since the massive fire in 2015 . Joko Widodo declared Presidential Instruction No. 11/2015 as vigorous law enforcement to control fire inside timber concession. Consequently, when a company is proven guilty, the government has the right to enforce sanctions ranging from imposing a fine to revoking a business license. These forest fires keep happening inside or outside timber concession, peatland, or forest area. Given the state of affairs, the study seeks to address the forest fire reoccurrence and their size using regional-spatial information. Specifically, the following two questions are addressed. First, do the recurrent fires positively correlate with timber concession, peatland, and forest area? Second, does the fire size positively correlate with timber concession, peatland, and forest area with recurring fire?

The fire has a high likelihood of reoccurring inside the peatland, and the previous studies established that the nature of the peatland makes this area nonadaptive to fires. Human activities inside the peatland make this area sensitive to deforestation (Murdiyarso et al., 2010; Page et al., 2009a). Activities within dry peatland can ignite a fire on the surface. This has been reported in several studies, and they suggested that it is essential to keep the surface humid and keep the water table level under control to prevent fire (Langner and Siegert, 2009; Wooster et al., 2012; Wösten, et al., 2006; Yulianti et al., 2012). Sadly, many people still do not know these facts and consider peatland as an unproductive swamp that should be drained. In fact, it was activities in peatland and swamp that lead to 1997-98 forest fires in South Sumatra (Tacconi et al., 2006). Besides, the Ministry of Environment and Forestry reported that one-third of burned areas are inside peatland.

Previous studies show that forest fire correlates with timber concessions. Hoffman et al. (1999), Potter and Lee (1998) and Stolle et al. (2013) found the evidence from satellite imagery and maps of active fires (hot spots), suggesting that the most extensive fires and smoke originated from the governmentowned plantation and logging timber concessions. Another research by Tacconi et al. (2006) also supported this argument by stating that the development of timber companies, settlements, and roads tends to increase fire risk. Besides timber concession, past literature revealed that forest area is associated with forest fire reoccurrence. Due to forests' use as the primary source of life, people try to utilize them easily and cheaply. (Purnomo et al., 2017) described that people use fire for land clearing because it is less expensive than using mechanical tools. Additionally, the forest area that is not inside the timber concession boundary has a high risk of being burned (Gaveau et al., 2016).

Even though some studies in forest fire issues have been conducted using a similar method and similar data type, most of them focused on investigating only a one-time significant forest fire incident. However, now in Indonesia, forest fire happens occasionally every year. Thus, this research can be considered to complement the previous studies by combining not only the spatial process but also conducting the statistical procedure. Moderately, this study tries to fill in the gap by examining the forest fire reoccurrence. Given the literature, it can be hypothesized that forest fire can occur and reoccur in peatland, timber concession, and forest areas. Comparatively, in terms of the size of the burned area, it can be hypothesized that the size is larger after fire reoccurrence because people feel safe to make repeating combustion. This research uses probit and tobit regressions to test the hypotheses by utilizing the regional-spatial panel data from The Ministry of Environment and Forestry of Indonesia.

The strength of this study is using time-series data of the burned areas from 2015 to 2018. Indonesia suffered from a widespread fire in 2015 , and it kept on going three years later. Previous studies used only one single specific data and did not consider the reoccurrence of fire. There is a high chance that one area burned more than once while the geographic method could capture the reoccurrence event. The empirical method is used to see the correlation of forest fire reoccurrence on the other variables. The highlight of this research is to emphasize the trade-off of government policy for preventing the environment and investment in the forest area. 


\section{Methodology}

This study uses regional-spatial panel data from the Ministry of Environment and Forestry (MoEF) from 2015 to 2018, such as area size, timber concession, peatland, and forest area. This data can be accounted for because it has passed the field survey checking. The original form of unit analysis of the dependent variables is polygons of burned areas (hectare). The independent variables consist of the peatland, forest area, and timber concession in a polygon (hectare). Thus, this research transforms these polygons from numerical into categorical data.

This study utilizes two procedures, spatial and empirical. The first procedure of the spatial process aimed to form the panel data structure. The panel data were further analyzed using probit regression. This empirical method is used to see the correlation of forest fire reoccurrence on the other variables. Tobit regression is later applied to see the correlation between the size of forest fire and other variables,. Finally, the statistical regressions will generate the marginal effects of the independent variable.

This study focuses on the occurrence and size of the burned area as dependent variables. Ministry of Environment and Forestry (MoEF) generates the burned area data based on Moderateresolution Imaging Spectroradiometer (MODIS) for hotspot and Land Satellite (LANDSAT) with a high resolution. The first independent variable imperative to discuss is the peatland. Peatland is characterized by organic material decomposition and water. This spatial data is based on MOEF regulation number P.60/2019, with a scale of 1:250.000.

Another independent variable is the forest area, which also comes from the MoEF scale of $1: 250.000$. The definition of forest area in this study is the areas or regions with legal status, function, location, and the boundary as a state land forest. The forest area has three functions: conservation, preservation, and production. People can utilize forests under the state's control, and its use is limited only in the production area. All activities in the forest must be based on a clear legal basis related to the forest area. This legal basis is closely related to the risk of illegal deforestation.

The third independent variable is timber concession, which also comes from MoEF. Timber concessions are firms that have a legal business license from the government to use the forest products inside the forest area. The government grants this license to individuals, cooperatives, Indonesian private's companies, and state or regional government-owned companies. The licensing process includes boundary arrangement, a recommendation from the governor, technical supervision, proposal evaluation, mapping the area requested. Additionally, if the areas are legitimate, the timber concessions have to pay non-tax state revenue. Indonesia's forestry law states that timber concessions must be responsible for fires in their area.

Furthermore, there are other kinds of utilization in forest production areas, such as non-timber production and environmental services. However, these types of users do not involve in cutting down trees. This study excludes these non-timber and environmental services firms. Even though palm oil plantation also causes forest fire, this study eliminates oil plantation to focus only on the forest area. This is because the location is outside of the forest boundary.

This study modifies polygons, originally in a hectare, into binary numbers by implementing the spatial process illustrated in figure 1. This process starts from intersecting every polygon of the burned area from 2015 to 2018. The non-overlapping polygons indicate an unburned area (identified as 0) or burned once (identified as 1). On the other hand, overlapping polygons mean that the locations experience fires more than once ( 2 = burned twice; 3 = burned three times, $4=$ burned four times). Then, for the fire reoccurrence context, the repeating burned area is valued as one and not repeating valued as 0 .

The next procedure is intersecting the polygon of forest area, peatland, and logging timber concession with repeating burned areas. These new classifications consist of categorical data 1 and 0 . In detail, this research identifies repeating burned areas inside timber concession, inside the forest area, and inside peatland as 1 . Otherwise, the fire reoccurrence outside these boundaries is classified as 0 . Thus, the panel data is ready to be examined using the probit model. 


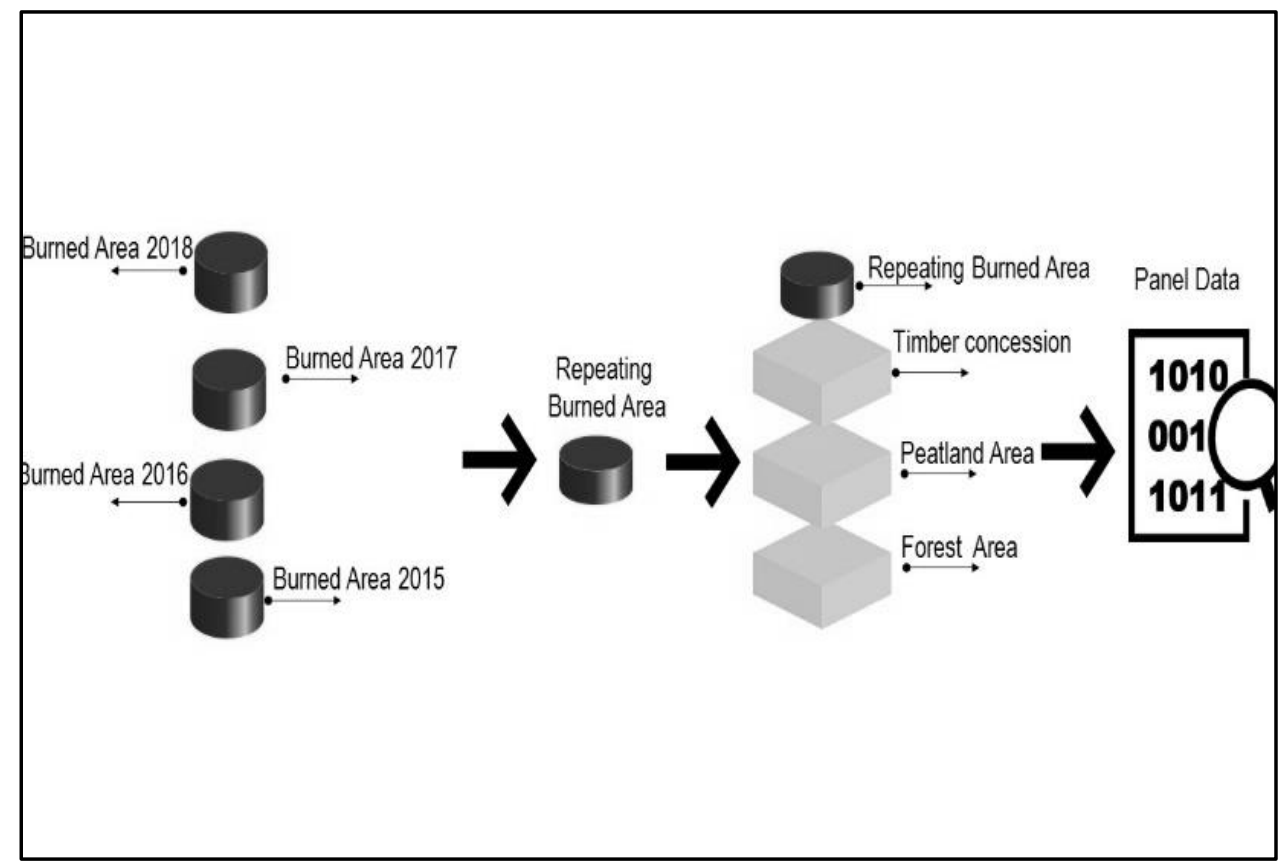

Figure 1. Spatial Methodology of Repeating Burned Area (Own elaboration)

The illustration of fire reoccurrence is drawn in figure 2. The burned area location is in Papua Province, east part of Indonesia. This forest fire map consists of information related to peatland, timber concession, and forest area. CONS means the timber concession area, Forest_ID refers to the forest area, Fire_Repeat shows the forest fire repeating, LUAS_ALL implies the size of the polygon in a hectare, Peat_ID illustrates the peatland, and repeat is how many times the fires repeat. Additionally, the dark area on the map shows the repeating burned area (identified as 1 ), and the light area is otherwise (0). The dark one represents the area outside the timber concession (0), outside the peatland $(0)$, inside the forest area (1), and has the size 155.64 Hectare.

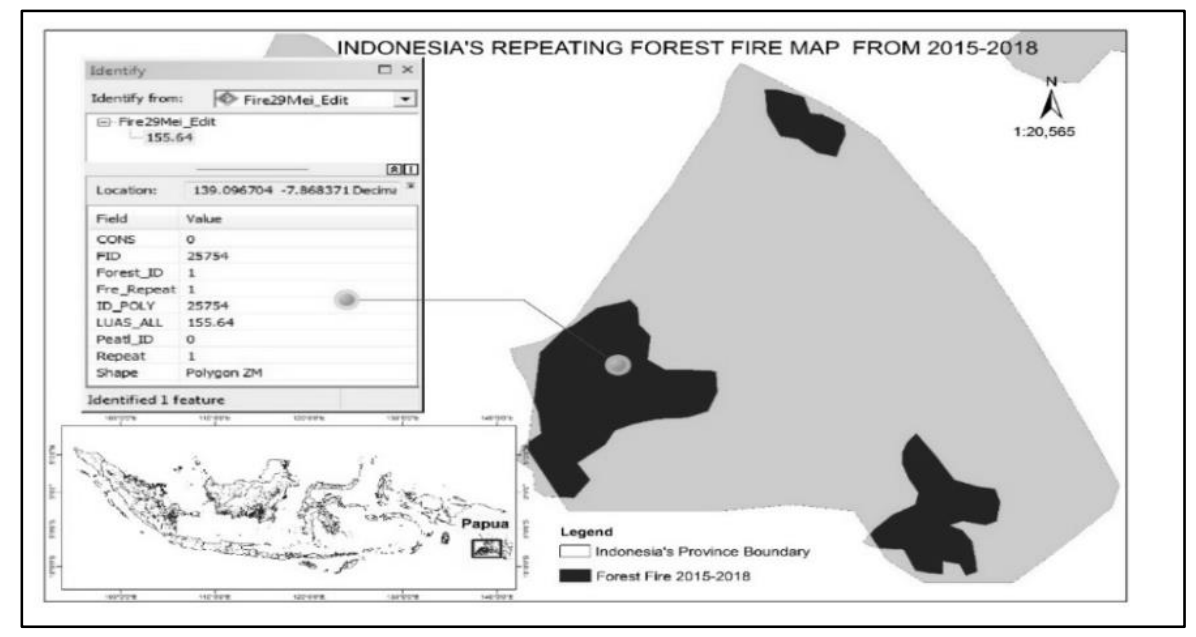

Figure 2. Burned Area (Own elaboration)

This spatial process generates forest fire polygons from 2015 to 2018, including variables needed for this research. In detail, the polygons contain information about fire occurrence, size, and repeating (or not) events. Besides, the location of fires, inside (outside) timber concessions, peatland, and forest area are included as influential factors through this process. As explained before, the polygons are now categorical. All variables involved in this spatial panel data are described in Table 1 
Table 1: Variables included in the analysis.

\begin{tabular}{|c|c|}
\hline & Type \\
\hline Dependent Variables & \\
\hline $\begin{array}{l}\text { Forest Fire re-occurence } \\
\text { (1=100\% Re-occurrence; } 0=\text { otherwise) }\end{array}$ & Categorical \\
\hline $\begin{array}{l}\text { Forest Fire Repeating Event } \\
(0=\text { not burn } 1=\text { burned one time; } 2 \text { =burned twice; } 3 \\
\text { =burned three times } 4=\text { burned four times) }\end{array}$ & Categorical \\
\hline Forest Fire Size (Hectare) & Numeric \\
\hline Variable of Interest & \\
\hline $\begin{array}{l}\text { Timber concession } \\
\text { (1= inside timber concession ; } 0=\text { outside timber concession) }\end{array}$ & Categorical \\
\hline $\begin{array}{l}\text { Peatland } \\
\text { (1= inside peatland ; } 0=\text { outside peatland })\end{array}$ & Categorical \\
\hline $\begin{array}{l}\text { Forest Area } \\
\text { (1= inside forest area } ; 0=\text { outside forest area }\end{array}$ & Categorical \\
\hline
\end{tabular}

Source: Own elaboration

The panel probit regression is suitable to examine the correlation of dependent and independent variables, regarding dependent variables that are discrete binary data, which are repeat or not repeat burned areas (the values of 0 and 1 ). The methodology also depends on the research objective, and this study explains the correlation between the peatland, the forest area, timber concession, and the repeating fire. Then, the marginal effect of a change in the explanatory variable on the dependent variable's expected value is calculated.

The following basic specification is used :

Repeating $_{\text {area }}=\beta 0+\beta_{1}$ concession $+\beta_{2}$ peatland area $+\beta_{3}$ forest area

Repeating is the dependent variable that describes an area that has been burned more than once. The variable was set as a dummy variable, in which 1 is equal to the area burned more than once, while 0 is equal to otherwise. Timber concession is the dummy variable that indicates the area of timber concession. The value is 1 when the fire occurs inside the timber concession and 0 if it occurs outside the timber concession. Peatland is also a dummy variable referring to the area of peatland. The value of 1 is assigned when burned area takes place inside the peatland, and 0 is given if it takes place outside the peatland. Forest area is another dummy variable indicating the forest area. The value is 1 when burned area occurs inside the forest and 0 if it happens outside the forest.

The next research objective is to know the influence of repeating fire, timber concession, peatland, and forest boundary on the size of forest fire in Indonesia. In this study, tobit is an appropriate method since the outcome variable (burned area size) can be either a positive or a zero. In other words, this research cannot use the linear regression model because in linear regression, predictions may be negative, and the effects of explanatory variables are linear. Thus, tobit regression is an appropriate way for these kinds of circumstances.

Then, for this case, The following basic specification is used

$y^{*}=\beta_{0}+\beta_{1} x_{1}+\cdots+\beta_{k} x_{k}+u, u \mid x \sim N\left(0, \delta_{2}\right)$

$y=\max \left(0, y^{*}\right)$

Where $y^{*}$ is the observable latent variable of burned area size, while $x_{1}$ to $x_{k}$ is the independent variable (timber concession, forest area, peatland). $E, y$ is the observable outcome of burned area size.

Thus, this research can be considered to complement the previous studies by combining the spatial process and the statistical procedure. These procedures enable us to fully utilize the nature of the regional-spatial panel data by transforming the information into categorical and numerical variables. probit regression is utilized for the examination of timber concession, peatland, and forest boundary that correlate with the occurrence of forest fire in Indonesia. Tobit is used to test the association of timber concession, peatland, and forest boundary on the size of forest fire in Indonesia. Both of these quantitative analyses are needed to explain the possibility of forest fire reoccurrence and its size. The 
probit regression is suitable for analyzing the correlation between the fire's repeating event and every independent variable. The tobit regression is appropriate for the analysis of the size of the repeating burned area. This study can extend the data from 2000 to 2020 and build up the cross variable analyses for future research. An example is the fire event analysis that reoccurs in the timber concession inside the peatland area.

\subsection{Trends and Situation of Forest Fire in Indonesia}

This paper uses two kinds of data processing, spatial and statistical processing. After conducting the spatial processing, the study generates information about the frequency and location of repeated fires. Table 2 shows the percentages of forest fire repeating events. The percentage of fires gradually decreases after the first fire. The share of the repeating area is approximately $5.03 \%$ (Twice, Three Times, Four Times) of the total area, and the majority of fires occur only two times in the same area (4.5\%). Such a low figure indicates that after 2015 people no longer intend to ignite the fire in the same location twice

Table 2. Forest Fire Repeating Event

\begin{tabular}{ll}
\hline Repeating Event & Percent (\%) \\
\hline Not Burn & 77,2 \\
Once & 17,77 \\
Twice & 4,5 \\
Three Times & 0,5 \\
Four Times & 0,03 \\
\hline \multicolumn{2}{c}{ source: own elaboration }
\end{tabular}

Table 3 below show that from 2015 to 2018, the trend fluctuates. Moreover, from 2015 to 2016, the number of fires sharply decrease from 48792 to 5696 before it steadily rises again in 2017 and 2018. There are 16 possibilities of repeating fire from 2015 to 2018 because fire can occur randomly. For instance, peatland forests were scorched in 2015, and the fires came back in 2017. Another alternative is that it may be scorched every year. The existence of these forest fires is displayed in table 3 . The table shows that most forests are burned in the same location twice, in 2015 and 2018. Even though the statistical analysis shows that burned frequency is three to four times, the observation number is small.

Table 3. The Frequency of Forest Fire Occurring

\begin{tabular}{lll}
\hline Fires Occurrence (Year) & Burned Frequency & Number of Observation \\
\hline Not Occur & 0 & 488156 \\
2015 & 1 & 48792 \\
2016 & 1 & 5696 \\
2017 & 1 & 12316 \\
2018 & 1 & 45256 \\
2015 and 2016 & 2 & 2064 \\
2015 and 2017 & 2 & 2964 \\
2015 and 2018 & 2 & 17392 \\
2016 and 2017 & 2 & 684 \\
2016 and 2018 & 2 & 2224 \\
2017 and 2018 & 2 & 3452 \\
2015,2016 and 2017 & 3 & 196 \\
2015,2016 and 2018 & 3 & 956 \\
2015,2017 and 2018 & 3 & 2068 \\
2016,2017 and 2018 & 3 & 320 \\
$2015,2016,2017$ and 2018 & 4 & 176 \\
Total & & 632.712 \\
\hline source: own elaboration & &
\end{tabular}

As a climate factor, ENSO plays an essential role in forest fire events because it triggers fire ignition. ENSO or popularly known as El Niño, causes abnormal temperature and precipitation rainfall rate, which can manifest into extensive drought around the regions affected. Figure 3 shows that an increase in 2015 hotspots started in August, peaked in September and October, and then dropped dramatically in November. The trend occurs in all provinces in Indonesia. A decrease in hotspot data by November was caused by increased rainfall. This study argues that forest fire in Indonesia keeps appearing every year, or in other words, forest fire will appear in the El Niño season (or not). The fire will appear as the result of abnormal temperature, precipitation, and the drying peatland. However, fire events will increase during the dry season in rainforest countries if fuels are abundant. El Niño may occur, but fire activities will not take place if enough fuel is unavailable. 


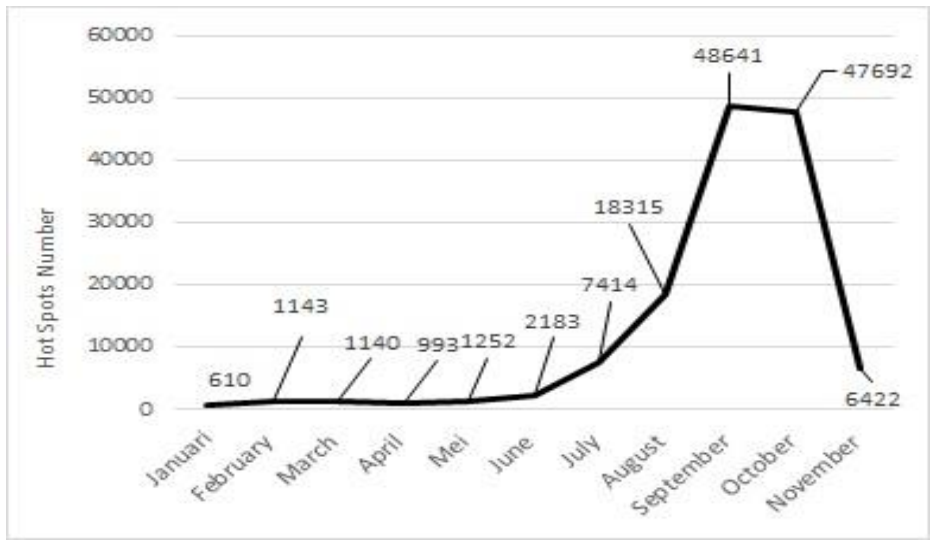

Figure 3. Hot Spots in 2015 (Indonesia's Ministry of Environment and Forestry, 2015)

Figure 4 below shows that the forest fire reoccurrence in Indonesia has a specific spatial pattern. For instance, as the world bank mentioned earlier, Central Kalimantan, South Sumatra, South Kalimantan, West Kalimantan, and Papua suffered from a massive fire in 2015 and fire reoccurrences for the past three years. All of these provinces had the same land traits; they all are peat provinces. In contrast, in East Nusa Tenggara, which is mainly covered by savanna grassland, the fire is used to cultivate grass for cattle and improve hunting visibility (Dennis et al., 2005; Tacconi and Ruchiat, 2006).

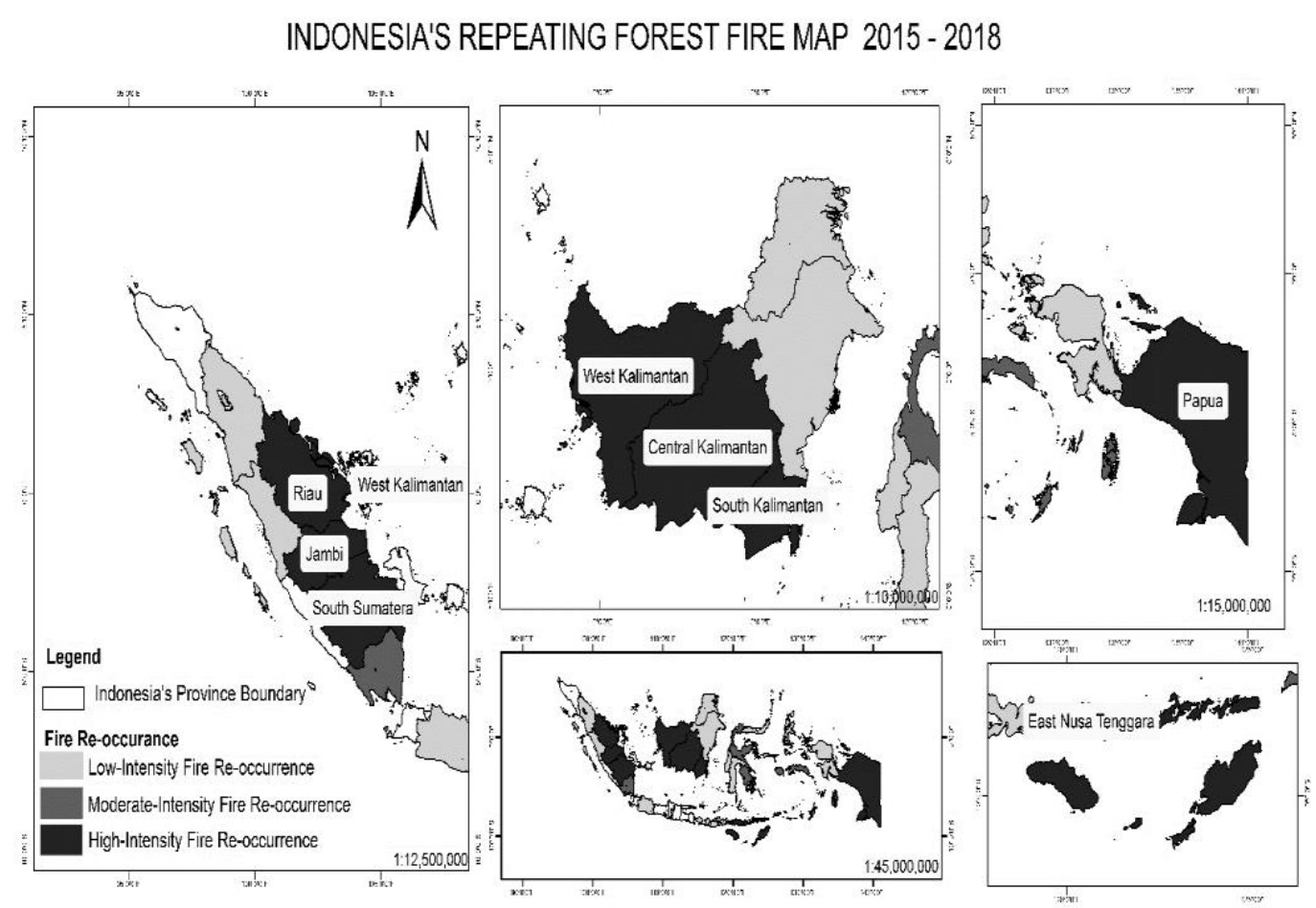

Figure 4. Repeating Forest Fire Map 2015 - 2018 (Own elaboration)

Figure 5 shows spikes in the number in 2004, 2006, 2009, and 2015 of hotspots compared to any other year in the last 16 years. The catastrophe related to the El Nino phenomenon was befalling in Indonesia at that time. Land and forest fire caused $80 \%$ of the area in Sumatra and Kalimantan covered in dense smoke. In 2015, after the massive fire, efforts to prevent and manage land and forest fire disasters ran well while the number of hotspots drastically dwindled. 


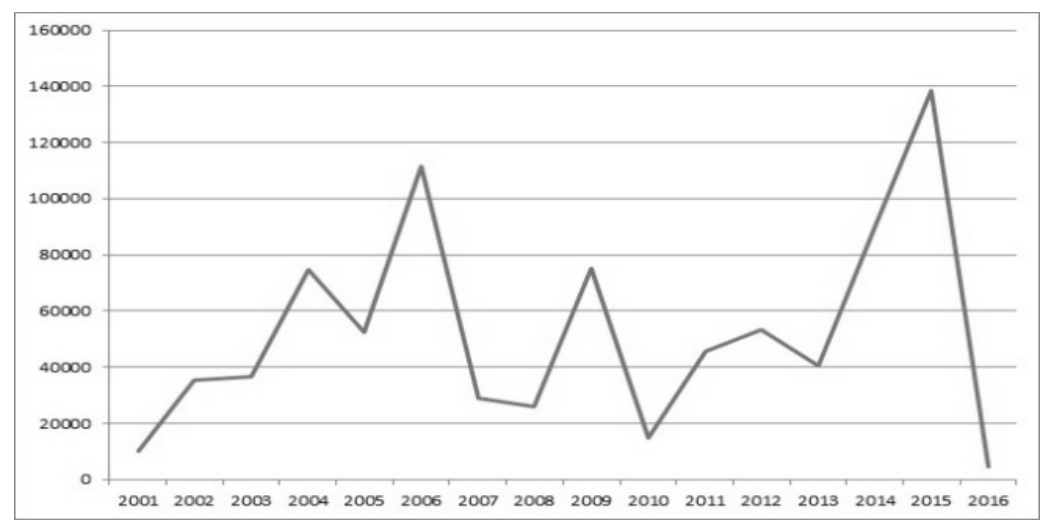

Figure 5. Hot Spots from 2001-2016 (Indonesia's Ministry of Environment and Forestry, 2016)

The climate is difficult to control; hence the peatland easier to manage. The peatland should have proper water table management since humid peat is more adaptable to fire. (Page et al., 2004) reveal that during the EI Niño season, groundwater may decrease and creates peatland fire. Additionally, (Jauhiainen et al., 2014) opine that extreme drainage peatland can lower the canopy, exposing peatlands to fiercer solar penetration. Deforestation activities can increase the temperature of the peatlands.

Indonesia's government tries to protect and restore degraded peatland by issuing several policies. Presidential Instruction No. 8 of 2015 suggests a moratorium license for timber concessions to promote deforestation in the peatland. Another policy that governs the restoration of the production forest is Environment and Forestry Ministerial Decree No. 77/2015. This regulation is considered the government's effort to give an understanding of how to manage timber concession within Indonesia's peatlands.

\subsection{Challenges in Combating Forest Fire}

The government programs to prevent fires sometimes meet many obstacles. Further, the loss of the peatland from 2015 to 2018 is described in Figure 6. The government succeeded in diminishing burned areas to only $8 \%$ in 2017; however, in 2018 , the peatland fire increased to $25 \%$. The increasing number of fires in 2018 indicates that the number of land degradation is way too large, and it takes time to become wet again through dry season onset. The peatland loss is hard to rehabilitate quickly because it takes more than a thousand years to form the peat layer.

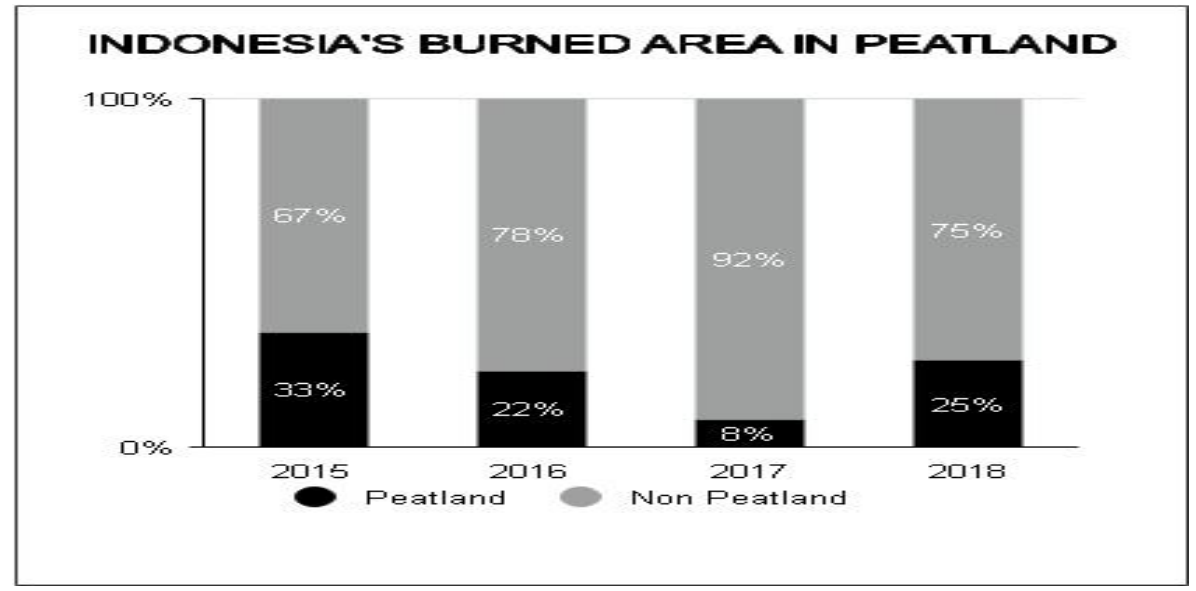

Figure 6. Indonesia's burned area within peatland (Indonesia's Ministry of Environment and Forestry, 2018)

Figure 7 displays a comparison between fires in forest areas and non-forest areas. The share of fire events in forest areas increases from just 30 percent in 2015 to over a half in 2018 . There is a possibility that the burned areas have already been open areas without dense canopy. Furthermore, fire is likely to appear from a bush or shrubland near the forest area, and because of the nature of fire, it can easily infiltrate the forest. 


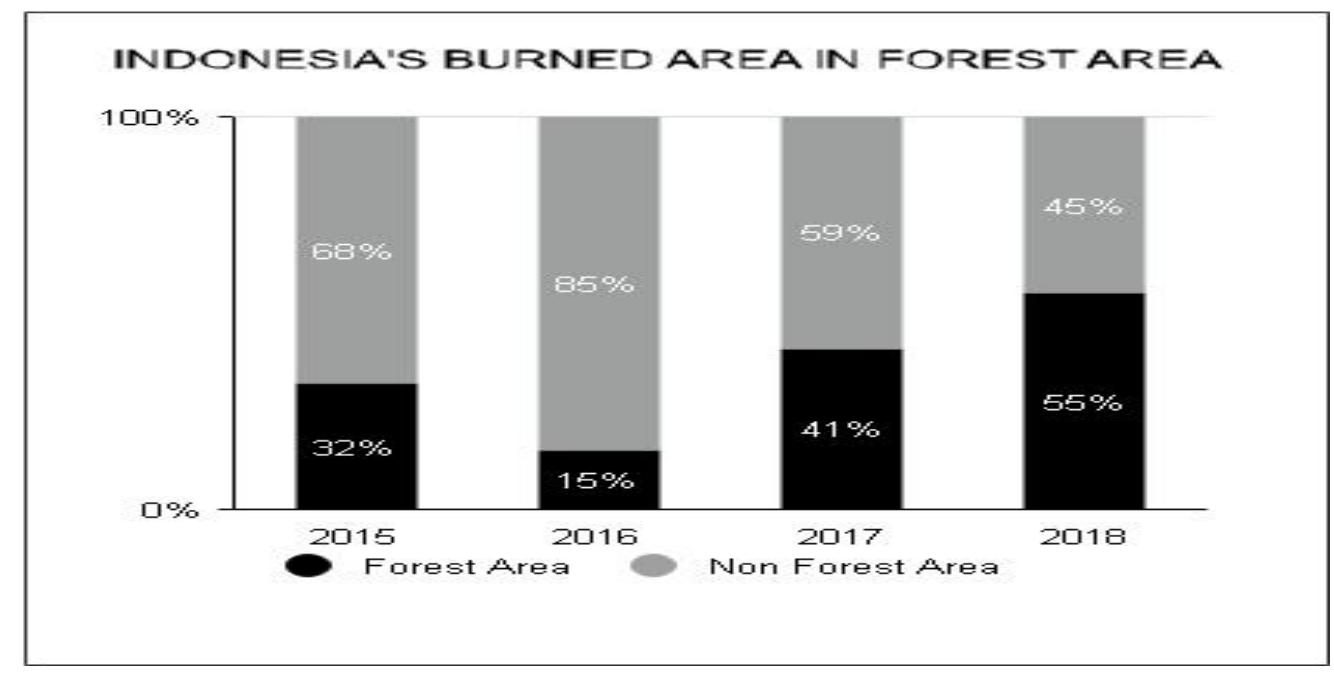

Figure 7. Indonesia's burned area within the forest area (Indonesia's Ministry of Environment and Forestry, 2018)

These two scenarios make sense if we adopt the forest-fire exploitation cycle (Byron and Shepherd, 1998; Nepstad et al., 1999). The cycle starts by opening the forest for logging or road construction. Next, the sun can easily penetrate the forest floor and decrease moisture so the resulting forest will dry out. Once the tree cuts, the forest suddenly loses the immunity to fight the fire, and the deadwood that is left behind will support combustion as a fuel. Subsequently, after the forest was on fire, it will provide more open space, which is more inflammable. Consequently, the forest will completely be replaced by grassland if this cycle continues.

The composition between timber concession and repeating forest fire shows in the crosstab table below. Table 4 displays that $0.34 \%$ of fires occur more than once inside the timber concession. This small number of fire occurrences indicates that timber firms try their best to keep the business area clear from fire throughout the time. However, as seen in table 4, more than $90 \%$ of fires are from outside timber firms' working areas. Consequently, firms have two obligations. They must prevent the fire from appearing in their areas and keep the fire away from their surroundings.

Table 4. Crosstab forest fire and timber concession

\begin{tabular}{cllll}
\hline & & \multicolumn{2}{c}{ Timber concession } & \multicolumn{1}{c}{1} \\
\hline Repeating & 0 & $545,272(86,18 \%)$ & $54,944(8,68 \%)$ & $600,216(94,86 \%)$ \\
& 1 & $30,340(4,8 \%)$ & $2,156(0,34 \%)$ & $32,496(5,14 \%)$ \\
Total & & $575,612(90,98 \%)$ & $57,100(9,02 \%)$ & $632,712(100 \%)$ \\
\hline source: own elaboration & &
\end{tabular}

Besides the big scale corporation, a small scale of human activity whose livelihood depends on the forest also exists. This research argues that the small scale of human activities for economic intention is hard to measure. Also, the data that prove small-scale human activities causing the fire are limited. The vast area of the Indonesian forest makes people easy to enter the forest boundary and ignites a fire. Gaveau et al. (2017) demonstrate that satellite imagery can show the pattern of small-scale farmers' activities. The small parcels of irregular shape, size, and direction are an indication of small scales activities. This satellite delineation method is suitable for a limited area such as Riau Province. In contrast, it is challenging to make a delineation for all Indonesia regional areas.

Table 5 reveals that although the share of repeating fire in the peatland is relatively small at only $1,84 \%$, the government cannot be off guard to prevent fire because once the peatland is burned, it will be difficult to put out. Consequently, if the fire appears for weeks in the peatland, it will produce more smoke than other forest types (Yeager et al., 2003). This type of forest generates carbon dioxide two times more than other forest types (Varma, 2003). The world bank counts that the effect of haze causes more than 500.000 cases of acute respiratory infections, and 19 people passed away in 2015. 
Table 5. Crosstab forest fire and peatland.

\begin{tabular}{cllll}
\hline & \multicolumn{1}{c}{0} & Peatland & \multicolumn{1}{c}{1} & \multicolumn{1}{c}{ Total } \\
\hline Repeating & 0 & $470,516(74,36 \%)$ & $129,700(20,5 \%)$ & $600,216(94,86 \%)$ \\
Total & 1 & $20,852(3,3 \%)$ & $11,644(1,84 \%)$ & $32,496(5,14 \%)$ \\
& & $491,368(77,66 \%)$ & $141.344(22,34)$ & $632,712(100 \%)$ \\
\hline
\end{tabular}

source: own elaboration

Before moving forward to repeating fire, we can see from table 6 that the gap between fire share inside and outside the forest is just $6 \%$. This data reveals two scenarios. First, people unintentionally ignite fires inside the forest area because they do not have enough knowledge about forest boundaries. The forest border sometimes vanishes over time, and people easily enter forest areas without pretension. Even though the legitimation of the forest boundary is drawn in a forest area map, sometimes people are not familiar with it. In Indonesia, more than $50 \%$ labor force is dominated by the lower level of education; most education levels are junior high school or below (Pratomo et al., 2020). A low level of education somehow forms people's mindset about forest boundaries.

Table 6. Crosstab forest fire and forest area.

\begin{tabular}{cllll}
\hline & \multicolumn{2}{c}{ Forest AREA } & \multicolumn{1}{c}{ Total } \\
\hline Repeating & 0 & $280,116(44,27 \%)$ & $320,100(50,59 \%)$ & $600,216(94,86 \%)$ \\
& 1 & $13,884(2.19 \%)$ & $18,612(2,94 \%)$ & $32,496(5,14 \%)$ \\
Total & & $294,000(46,47 \%)$ & $338,712(53,53 \%)$ & $632,712(100 \%)$ \\
\hline
\end{tabular}

source: own elaboration

The possibility is that the combustion actors are aware of the forest area; however, they keep burning it because they think no one owns the land, and they want to acquire it. However, the table shows that the fires appeared inside the forest area for approximately 53\%. Further, in terms of repeating fire, we can see that people choose to set fire at the same location inside the forest area $(2,94 \%)$; hence, they are not afraid to get caught by the authority. Besides, forest rangers do not have enough resources and supplies to control all areas. To put it in perspective, the total area of Indonesia's forest is 125 million hectares, while the number of forest rangers is only around 2650. In other words, one forest ranger must control 47 thousand forest areas.

Kalimantan even issued a Guideline for Land and Gardens Opening (Governor Regulation 52/2008, revised in 2010). It contains specific points about logging and burning forest for agriculture because a vast majority of people depend on logging and burning forest to sustain their livelihood.

Table 7 shows that all data except the burned area's size is categorical (the minimal values are 0 and maximal 1). In detail, the repeating forest fire on average is only 0.05 , nearly to 0 . The average of the burned area is 103 hectares, which equals ten times the rugby football field. The fire reoccurrences mostly happen outside the timber concession, as seen in the average value of this variable $(0,09)$. In contrast, the statistics reveal that more than half of the fire events appeared inside the forest boundary. On average, fire reoccurrence in the peatland area is only 0,22 , and it is insignificant compared to the forest area. This data reveals that people do not set fires in the same area twice. However, if people choose to do it, they choose the location outside the timber concession but still inside the forest boundary that does not have licenses. This statistic also reveals that people do not prefer to set fire on the peatland. 
Table 7. Summary statistics

\begin{tabular}{|c|c|c|c|c|}
\hline & Average & SD (....) & Min & $\bar{M}$ \\
\hline \multicolumn{5}{|l|}{ Dependent Variables } \\
\hline $\begin{array}{l}\text { Forest Fire Occurrence } \\
(0=\text { not repeating; } 1=\text { repeating) }\end{array}$ & 0.05 & 0.22 & 0 & 1 \\
\hline Forest Fire Size (ha) & 103,83 & 1825,26 & 0.000001 & 2 \\
\hline
\end{tabular}

\begin{tabular}{|c|c|c|c|c|}
\hline $\begin{array}{l}\text { Timber concession ( } 0 \text { = outside timber } \\
\text { concession; } 1 \text { = inside timber concession) }\end{array}$ & 0.09 & 0.28 & 0 & 1 \\
\hline $\begin{array}{l}\text { Peatland ( } 0=\text { outside peatland; } 1=\text { inside } \\
\text { peatland) }\end{array}$ & 0.22 & 0.42 & 0 & 1 \\
\hline $\begin{array}{l}\text { Forest Area }(0=\text { outside forest area, } 1= \\
\text { inside forest area) }\end{array}$ & 0.53 & 0.49 & 0 & 1 \\
\hline
\end{tabular}

\section{Results and Discussion}

This research has two objectives. The first is to reveal a correlation between every independent variable and the reoccurrence of fire. The second objective is to determine the relationship between the frequency repeating, peatland, timber concession, forest area, and the size of the forest fire. This study applies probit regression and calculates the marginal effect to answer the first research problem. Additionally, table 8 shows that the correlation of fire reoccurrence on timber concession is negative and is contrary to another variable.

Table 8. Marginal effects of estimated parameters for probit regression

\begin{tabular}{cc}
\hline Variable & Marginal effects \\
\hline Timber concession & $-0.221773^{* * *}$ \\
Peatland & $(0.0036)$ \\
& $0.349033^{* * *}$ \\
Forest Area & $(0.0023)$ \\
& $0.0060397 * *$ \\
*significant at the 10\%; *significant at the 5\% level; ***significant at the $1 \%$ level & $(0.0021)$ \\
source: own elaboration &
\end{tabular}

The result reveals that the chance of fire reoccurrence inside the timber concession is $22 \%$ lower than outside the timber concession. On the other hand, peatland has a higher probability of fire by $34.9 \%$ than outside the peatland. Fire reoccurrence is also $0.6 \%$ higher inside the forest area. Predictably, peatland contributes the highest share because of its flammable characteristic-dry peat can trigger fires. Thus, economic activities through deforestation and drainage of peat canal can lead to a fire.

The interpretation is consistent with the hypothesis that fire reoccurrence in the same location inside the peatland is higher than outside the peatland. This finding is aligned with the finding from Tacconi \& Ruchiat (2006), which explain that in the South Sumatra fire in 1997-98, the fire occurs because of commercial peat exploration. In the massive fire of 2015, around one-third of the burned area was peatland. It created a heavy haze covering a considerable part of Indonesia and the surrounding areas, bringing adverse effects to many sectors (World Bank, 2016).

The forest area results match the hypothesis that the risk of burning in the same location inside the forest area is higher than in the outside. This incident happens because people view the forest area as unclaimed land, and burning it is a simple step to claim the land (Purnomo et al., 2018). This finding corresponds to the research conducted by Cattau et al. (2016) and L. Tacconi et al. (2007). In Indonesia, the total size of the forest area is 125 million $\mathrm{Ha}$ and $67 \mathrm{Ha}$ for the non-forest area. However, half of the non-forest areas are occupied for settlement, cultivation, and infrastructure. Consequently, people enter the forest area to occupy it since they think the field is unowned. 
Nevertheless, the timber concession variable shows a different story. At the beginning of this research, it is hypothesized that timber concession has a positive correlation with repeating fire. However, after conducting tobit regression, the result reveals otherwise. The finding shows that the business owners consider the benefit of burning their land outweighs the government's sanction and punishment. Moreover, MoEF in 2018 informed that the government would impose a fine of up to 1.2 billion to a private company committing environmental crimes.

Table 9. Marginal effects of estimated parameters for tobit regression

\begin{tabular}{lc}
\hline Variable & Marginal effects (Ha) \\
\hline Repeating once & $-44.14085^{* * *}$ \\
& $(12.17)$ \\
Repeating twice & -39.22793 \\
& $(31.52)$ \\
Repeating three times & -41.44623 \\
& $(126.41)$ \\
Timber concession & $92.79891 * * *$
\end{tabular}

$(16.44)$

Peatland

$43.91306 * * *$

(10.63)

Forest area

$22.15367^{* *}$

(10.42)

\footnotetext{
${ }^{*}$ significant at the $10 \% ;{ }^{* *}$ significant at the $5 \%$ level; *** significant at the $1 \%$ level in $\mathrm{Ha}$ source: own elaboration
}

Table 9 above reveals several important highlights. First, the size of the burned area correlates with the first fire's repeating event. In detail, holding everything else constant, the burned area's size decreases by $44 \mathrm{Ha}$ when the first fire reoccurrence happens. On the other hand, the second and third fires are not significantly correlated with the burned area's size. The burned area becomes larger by 92 $\mathrm{Ha}$ if a fire occurs inside the timber concession, followed by $43 \mathrm{Ha}$ if it happened within the peatland. Thus, the burned area's size for fire reoccurrence inside the forest area increases by 22 Ha compared to outside the forest area.

This timber concession's result corresponds with the hypothesis that the size of forest fire has a positive correlation with timber concession. Unpredictably, the burned area gets larger, nearly about $100 \mathrm{ha}$. This result leads to the question; who is responsible for the fire inside the timber concession? The government sticks to article 41/1990 of the Forestry Law, which states that each timber concession is responsible for forest fires in their working areas. Hoffman et al. (1999), Potter and Lee. (1998), and Stolle et al. (2013) found evidence that the most extensive fires and the most significant amounts of smoke are originated from government-sanctioned corporate plantation development, logging timber concessions, and large-scale land-clearing/ development projects.

The peatland's tobit result is also coherent with the hypothesis, which informs that the fire polygon size will be larger if it occurs inside the peatland. In relation to this, the government shifts the approach from reactive to preventive by establishing the Peatland Restoration Agency in January 2016. This action was successful in reducing fire from $22 \%$ in 2016 to $8 \%$ in 2017. Even though peatland restoration is a long time effort, this study hopefully can encourage the regulator to preserve the peatland.

Furthermore, this study depicts that forest area positively correlates with the burned size and is in line with the hypothesis. There are some reasons people decide to set fire inside the forest. Firstly, Law enforcement is relatively weaker, and the government does not have enough resources to patrol all forest areas. Secondly, people depend too much on the forest to make livings; for instance, some community groups use fire as a tool for catching fish, finding honey, or making a small plot to grow rubber or maize. These community groups do not have mechanical tools and are not aware of the environmental standard for land clearing. Tomich et al. (1998) explain that fire is a tool to fight back in collective conflict. 
Besides, there is no cheaper alternative method than using fire for land clearing. Furthermore, fertilizers and pesticides are not as cheap as burning to increase soil fertility (Brandi, et al., 2015; INOBU, 2016)

The previous study has discussed fire occurrence in timber concession, peatland, and forest (Ardiansyah et al., 2017; Dennis et al., 2005; Gaveau et al., 2017; Tacconi et al., 2007). Thus, this study tries to supplement forest fire information by discussing reoccurrence fire in timber concession, peatland, and forest. This study reveals that the majority of fire reoccurs only two times. It does not repeat in the following year, and the coincidences of repeating fires are lower in the timber concession area. Besides, the burned area's size will decrease if the fire appears more than once in the same location. Additionally, the fire area will be larger if it appears inside timber concession, peatland, and forest area.

Furthermore, after the analysis, it can be concluded that fire reoccurrence has a negative association with the timber concession area. Compared to the peatland and forest area, it is easier for the government to manage the timber concession since the ownership is evident. Therefore, the government should strengthen law enforcement. For instance, the government may impose significant fines and revoke the business licenses for timber concessions proven to violate the rules.

As an unclaimed land, the same policies as the timber concession are hard to impose on the forest area. Unclear ownership is the main problem for the forest area. The officers cannot penalize fire actors as long as they are not caught when burning within the forest area. It is also impossible to prevent people from doing forest clearing because it is their livelihood. Furthermore, now government policy should focus on keeping the nature of peatland. Preventive action is more suitable in peatland than reactive action.

\section{Conclusion}

The forest fires in Indonesia have been repeating every year and reached a peak in 2015. Additionally, the government issues policies to prevent the fires from reoccurring. After 2015, the number of fires declines is aligned with the government intervention. This research focuses on the reoccurrence of forest fire events after the interference. Previously, it was hypothesized that fire repeating events and burned area size have a positive relationship with timber concession, peatland, and forest area. Thus, the two-step procedures, spatial and statistical, were conducted to examine the hypotheses. This research contributes to the previous studies by combining the spatial process and conducting the statistical procedure. The spatial process is used to construct a repeating fire dataset, while probit-tobit regression is applied to test the relationship between variables. This study utilized the panel data from the Ministry of Environment and Forestry from 2015 to 2018.

First, this research reveals the correlation between every independent variable and the fire reoccurrence. Most fires between 2015 and 2018 reoccured only twice, not in the following year inside peatland and forest areas. However, the second fire took place outside of the timber concession. For the first incident, the fire tends to have a larger size sequentially inside timber concession, peatland, and forest area. Second, a relationship is observed between frequency repeating, peatland, timber concession, forest area, and the size of the forest fire. Nevertheless, after fire reoccurrence, the size of the burned area shall be smaller. The result implies that the fire reoccurrence is highly related to the timber concession area and area types.

Finally, these research result shows that government intervention significantly reduced chances of forest fire reoccurrence. In other words, to avoid the repetition of a fire event and maintain the size of the burned area, Indonesia should keep improving the policies regarding forest timber concession and adjacent areas to further reduce forest fires event and the associated damage. As a peatland country, where natural fire possibly happens, almost $100 \%$ of forest and land fires in Indonesia are caused by human activities either intentionally or unintentionally.

This research suggests that recommendations must fit the needs of each different fire location. The policy that will be implemented in concession indeed has to consider private stakeholder characteristics. Furthermore, forest area policy must consider the nature of peatland and the needs of community groups.

A characteristic firm is to minimize cost and maximal profit. Government policy should regulate not only the punishment but also the reward. If timber concession is proven guilty, the government can freeze its business licenses or diminish its opportunity to get credit. In contrast, tax discount incentives should be awarded to companies that successfully maintain their area free of fire. This policy rewards both stakeholders. The company reduces its expenditure for paying tax while the government lowers the environmental cost to keep the forest safe. 
The policymakers should not forget public behavior within the peatland. They dry it to deforest and convert it into productive land. Public mindsets about peatland have to change, and the government should make an effort to change this behavior through policy. Instead of making the area dry, it is better to make it suitable for growing fish through the silvofishery program. The government may give incentives to the community around and within the peatland for fish seedlings. People will voluntarily maintain the water level inside peatland because it is profitable for them.

In contrast with timber concession, a different approach should impose on the forest area. Unclear ownership is the main problem for forest areas. Hence, the officer cannot impose penalties on the actor as long they are not proven guilty in the act set fires inside the forest areas. It is also impossible to prevent people from using the forests because it is their livelihood. An approach that is more reasonable to implement in forest areas is not to impose strict sanctions. However, together with the private sectors, the government has to introduce legal consequences for burning forests. Then, government or timber concession can also reward the community that can keep their forest safe from fire. Incentive policy success was implemented in Riau in 2015 when the great fire event appeared (Watts et al., 2019). However, imitating these programs should be through thoughtful research, trial and error because different locations generate different problems. Indeed, policymakers should first pay attention to what factors make people in other side parts of Indonesia's forest area voluntarily comply with the regulation. Cost and benefit, poverty, and alternative livelihood should be taken into consideration in future research.

\section{Acknowledgments}

The authors would like to thank Vid Adriison, Ph.D. (Faculty of Economics and Bussines, University of Indonesia) for research discussion and Koji KOTANI, Ph.D. (Rikkyo University) for his guidance, reviewing my work in detail, and providing helpful feedback.

\section{References}

(INOBU), I. B. (2016). A Profil of Palm Oil Smallholder and Their Challenges of Farming Independently. Jakarta: Inovasi Bumi.

Ardiansyah, M., Boer, R., \& Situmorang, A. P. (2017). Preface: International Conference on Recent Trends in Physics (ICRTP 2016). Earth and Environmental Science, 54(012058). https://doi.org/10.1088/1742-6596/755/1/011001

Brandi, C., Cabani, T., Hosang, C., Schirmbeck, S., Westermann, L., \& Wiese, H. (n.d.). Sustainability certification in the Indonesian palm oil sector: benefits and challenges for smallholders (No. 74). Studies.No Title. 2013.

Byron, N., \& Shepherd, G. (1998). Indonesia and the 1997-98 El Niño: Fire problems and longterm solutions. Commonwealth Forestry Review, 77, 236-236.

Cattau, M. E., Harrison, M. E., Shinyo, I., Tungau, S., Uriarte, M., \& DeFries, R. (2016). Sources of anthropogenic fire ignitions on the peat-swamp landscape in Kalimantan, Indonesia. Global Environmental Change, 39, 205-219. https://doi.org/10.1016/j.gloenvcha.2016.05.005

Dennis, R. A., Mayer, J., Applegate, G., Chokkalingam, U., Colfer, C. J. P., Kurniawan, I., Lachowski, H., Maus, P., Permana, R. P., Ruchiat, Y., Stolle, F., Suyanto, \& Tomich, T. P. (2005). Fire, people and pixels: Linking social science and remote sensing to understand underlying causes and impacts of fires in Indonesia. Human Ecology, 33(4), 465-504. https://doi.org/10.1007/s10745-005-5156-z

Gaveau, D. L. A., Pirard, R., Salim, M. A., Tonoto, P., Yaen, H., Parks, S. A., \& Carmenta, R. (2017). Overlapping Land Claims Limit the Use of Satellites to Monitor No-Deforestation Commitments and No-Burning Compliance. Conservation Letters, 10(2), 257-264. https://doi.org/10.1111/conl.12256

Gaveau, D. L. A., Sheil, D., Husnayaen, Salim, M. A., Arjasakusuma, S., Ancrenaz, M., Pacheco, P., \& Meijaard, E. (2016). Rapid conversions and avoided deforestation: Examining four decades of industrial plantation expansion in Borneo. Scientific Reports, 6(October 2015), 1-14. https://doi.org/10.1038/srep32017

Hoffman, A. A., Hinrichs, A., \& Siegery, F. (1999). Hoffman et al., 1999 - Fire damage in EaKal in 
97-98.pdf (pp. 1-5).

Jauhiainen, J., Kerojoki, O., Silvennoinen, H., Limin, S., \& Vasander, H. (2014). Heterotrophic respiration in drained tropical peat is greatly affected by temperature - A passive ecosystem cooling experiment. Environmental Research Letters, 9(10). https://doi.org/10.1088/1748-9326/9/10/105013

L., P., \& J., L. (1998). Tree planting in Indonesia: trends, impacts and directions. Tree Planting in Indonesia: Trends, Impacts and Directions, 62(18). https://doi.org/10.17528/cifor/000414

Langner, A., \& Siegert, F. (n.d.). Spatiotemporal fire occurrence in Borneo over 10 years. Global Change Biology, 15(1), 48-62. In 2009.

Murdiyarso, D., Dewi, S., Lawrence, D., \& Seymour, F. (2010). Indonesia's forest moratorium: A stepping stone to better forest governance?. Cifor.

Nepstad, D. C., Veríssimo, A., Alencar, A., Nobre, C., Lima, E., Lefebvre, P., Schlesinger, P., Potter, C., Moutinho, P., Mendoza, E., Cochrane, M., \& Brooks, V. (1999). Large-scale impoverishment of amazonian forests by logging and fire. Nature, 398(6727), 505-508. https://doi.org/10.1038/19066

Page, S, Banks, C, Rieley, J, Jauhiainen, J, Vasander, H. (n.d.). The role of tropical peatlands in carbon storage and carbon cycling. In: Peatlands in the Global Carbon Cycle, The 2nd International Symposium. 25-30 September 2009, Prague, p. 22.

Pratomo, D. S., Syafitri, W., \& Anindya, C. S. (2020). Expanding Middle Class in Indonesia. The Journal of Indonesia Sustainable Development Planning, 1(3), 307-312. https://doi.org/10.46456/jisdep.v1i3.103

Purnomo, H., Okarda, B., Dewayani, A. A., Ali, M., Achdiawan, R., Kartodihardjo, H., Pacheco, P., \& Juniwaty, K. S. (2018). Reducing forest and land fires through good palm oil value chain governance. Forest Policy and Economics, 91(January), 94-106. https://doi.org/10.1016/j.forpol.2017.12.014

Purnomo, H., Shantiko, B., Sitorus, S., Gunawan, H., Achdiawan, R., Kartodihardjo, H., \& Dewayani, A. A. (2017). Fire economy and actor network of forest and land fires in Indonesia. Forest Policy and Economics, 78, 21-31. https://doi.org/10.1016/j.forpol.2017.01.001

Stolle, D., \& Micheletti, M. (2013). Political consumerism: Global responsibility in action. Cambridge University Press.

Tacconi, L., Moore, P. F., \& Kaimowitz, D. (n.d.). Fires in tropical forests - What is really the problem? Lessons from Indonesia. Mitigation and Adaptation Strategies for Global Change, 12(1), 55-66. 2007.

Tacconi, L., Moore, P. F., \& Kaimowitz, D. (2007). Fires in tropical forests - What is really the problem? Lessons from Indonesia. Mitigation and Adaptation Strategies for Global Change, 12(1), 55-66. https://doi.org/10.1007/s11027-006-9040-y

Tacconi, Luca, \& Ruchiat, Y. (2006). Livelihoods, fire and policy in eastern Indonesia. Singapore Journal of Tropical Geography, 27(1), 67-81. https://doi.org/10.1111/j.14679493.2006.00240.x

Tomich, T. P., Fagi, A. M., De Foresta, H., Michon, G., Murdiyarso, D., Stolle, F., \& Van Noordwijk, M. (1998). Indonesia's fires: smoke as a problem, smoke as a symptom. Agroforestry Today, 10, 4-7.

Varma, A. (2003). The economics of slash and burn: A case study of the 1997-1998 Indonesian forest fires. Ecological Economics, 46(1), 159-171. https://doi.org/10.1016/S09218009(03)00139-3

Watts, J. D., Tacconi, L., Hapsari, N., Irawan, S., Sloan, S., \& Widiastomo, T. (2019). Incentivizing compliance: Evaluating the effectiveness of targeted village incentives for reducing burning in Indonesia. Forest Policy and Economics, 108(98), 101956. https://doi.org/10.1016/j.forpol.2019.101956 
Wooster, M. J., Perry, G. L. W., \& Zoumas, A. (n.d.). Fire, drought, and El Niño relationships on Borneo (Southeast Asia) in the pre-MODIS era (1980-2000). Biogeosciences, 9(1). 2012.

World Bank. (2016). The Cost of Fire: An Economic Analysis of 'Indonesia's 2015 Fire Crisis. In Indonesia Sustainable Landscapes Knowledge Note: 1. World Bank Group.

Wösten, J. H. M., Clymans, E., Page, S. E., Rieley, J. O., \& Limin, S. H. (n.d.). Wösten, J. H. M., Clymans, E., Page, S. E., Rieley, J. O., \& Limin, S. H. (2008). Peat-water interrelationships in a tropical peatland ecosystem in Southeast Asia. Catena, 73(2), 212-224. 2008.

Yeager, C. P., Marshall, A. J., Stickler, C. M., \& Chapman, C. A. (2003). Effects of Fires on Peat Swamp and Lowland Dipterocarp Forests in Kalimantan, Indonesia. Tropical Biodiversity, 8(1), 121-138.

Yulianti, N., Hayasaka, H., \& Usup, A. (2012). Recent Forest and Peat Fire Trends in Indonesia The Latest Decade by MODIS Hotspot Data. Global Environmental Research, 16(1), 105-116. 